\title{
KINETICS OF THE OXIDATION OF AQUEOUS SODIUM SULFITE SOLUTIONS WITH AIR
}

\author{
SHINJI OGAWA, Yoko SHIMIZU, SETSUJI TONE AND TsuTAo OTAKE \\ Department of Chemical Engineering, Faculty of Engineering Science, Osaka University, Toyonaka 560
}

The catalytic oxidation of aqueous sodium sulfite solutions by dissolved oxygen has been applied to the evaluation of mass transfer characteristics in gasliquid contactors. Therefore, the kinetics of this reaction has been studied by many workers. There are, however, some differences in the rate expressions in those studies.

In this work, the absorption rate of oxygen from air into aqueous sodium sulfite solutions was measured in the regime of the fast second-order reaction, with cobaltous sulfate as a catalyst, in a stirred cell. Effects of such variables as cobalt concentration, $\mathrm{pH}$ of the solution and temperature on the rate constant were investigated and the rate constant was expressed as a function of these variables.

\section{Experimental}

According to the review by Linek et $a l^{\theta}{ }^{\theta)}$, when air at atmospheric pressure is used and the sulfite concentration is larger than its critical value ${ }^{10)}$, the reaction rate of sulfite oxidation is second-order with respect to dissolved oxygen and zero-order with respect to sulfite. As a result, oxygen absorption into sulfite solutions can be considered as an absorption enhanced by this irreversible fast second-order reaction when the Hatta number ${ }^{2)}$ is a fully large value.

A Pyrex glass stirred cell with four baffle plates was used and set up in a water bath. The experimental conditions are shown in Table 1. The $\mathrm{pH}$ of the solution was adjusted by adding a proper amount of $1 \mathrm{~N}$ sulfuric acid and was measured by a $\mathrm{pH}$ meter. Sampling the liquid phase from the cell at fifteenminute intervals during the course of the absorption run, sulfite concentration and cobalt concentration were determined by iodometry and EDTA chelate titration, respectively.

From the mass balance, a relation between variation of the sulfite concentration in the cell and time was derived as follows.

\footnotetext{
Received Febuary 5, 1982. Correspondence concerning this article should be addressed to S. Ogawa. Y. Shimizu is now with Matsushita Electronics Corp., Nagaokakyo, Kyoto 617.
}

$$
\begin{aligned}
\Delta C & =C_{\mathrm{SO}_{3}{ }^{2-}}^{\mathrm{O}-}-C_{\mathrm{SO}_{3}{ }^{2-}} \\
& =\left\{2 \sqrt{\frac{2}{3}-k D_{\mathrm{O}_{2}}}\left(\frac{A}{V}\right)\left(\frac{p_{\mathrm{O}_{2}}}{H}\right)^{3 / 2}\right\} t
\end{aligned}
$$

A plot of $\Delta C$ against $t$ gave a good linear relationship in each run. The rate constant $k$ was calculated from the slope of each straight line by using Eq. (1).

\section{Results and Discussion}

\subsection{Effect of cobalt}

Log-log plots of rate constant $k$ against cobalt concentration $C_{\mathrm{Co}}$ are shown in Fig. 1 for various $\mathrm{pH}$, including the results* presented by other workers ${ }^{9.11}$.

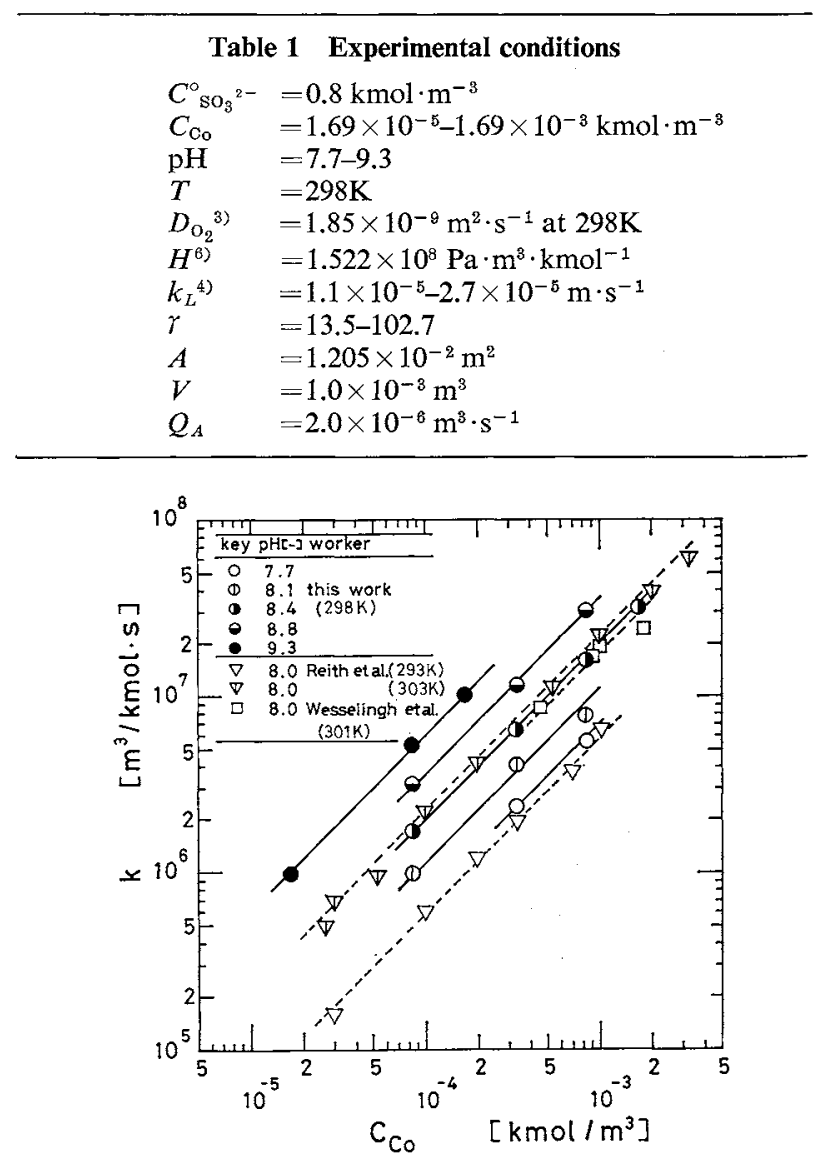

Fig. 1 Effect of cobalt concentration on secondorder rate constant

* All values of rate constants quoted from the literature were corrected by using the solubilities recomcomended by Linek et al. $^{\text {()) }}$. 


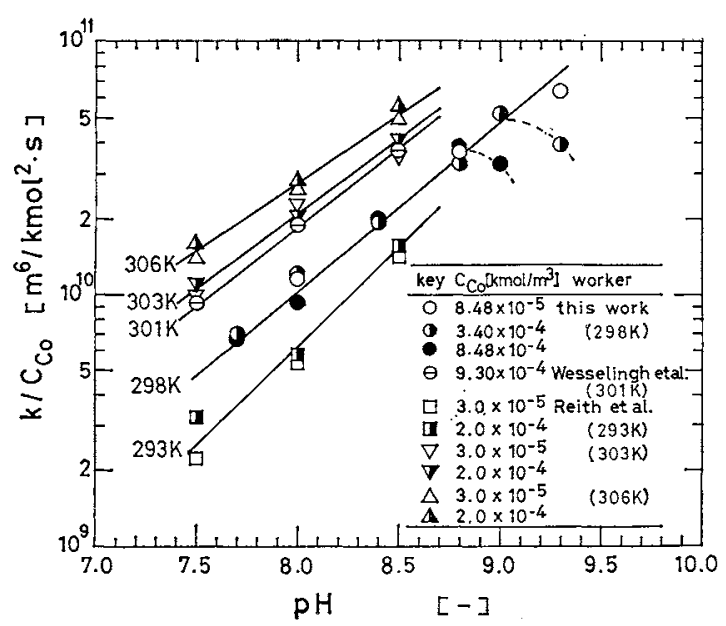

Fig. 2 Effect of $\mathrm{pH}$ of solutions on second-order rate constant

It is found from Fig. 1 that $k$ is first-order with respect to $C_{\mathrm{Co}}$ for each $\mathrm{pH}$. This agrees with the results already reported by other workers ${ }^{5-11}$.

\section{2 Effect of $\mathbf{p H}$ on the rate constant}

Several workers ${ }^{1,5-13)}$ have pointed out that the rate constant is strongly dependent on $\mathrm{pH}$. However, there are some differences in its dependency. In this work, the effect of $\mathrm{pH}$ on $k$ was investigated in the range of $7.7 \leqq \mathrm{pH} \leqq 9.3$. The plots of $k / C_{\mathrm{Co}}$ against $\mathrm{pH}$ are shown in Fig. 2 for various temperatures.

In Fig. 2, the dependency of $k$ on $C_{\mathrm{H}^{+}}$estimated from the slope of each straight line was found to be independent of $C_{\mathrm{Co}}$, but it was affected by temperature even in a narrow range.

Furthermore, Figure 2 shows that $k$ has a maximum at a high value of $\mathrm{pH}$ in the case of a large value of $C_{\mathrm{Co}}$. In the first-order regime with respect to dissolved oxygen, Onda et al. $^{\text {() }}$ and Yasunishi ${ }^{12)}$ reported the same tendency as this work. Onda et al. ${ }^{7)}$ explained that the presence of the maximum of $k$ was due to the formation of precipitates. In this work, however, no precipitates were found at $\mathrm{pH}$ slightly higher than the $\mathrm{pH}$ giving the maximum, which was the same as the result reported by Yasunishi ${ }^{12)}$.

The value of $\mathrm{pH}$ at the maximum of $k$ varied with $C_{\text {Co }}$. The condition where $k$ has its maximum value is approximately correlated as follows.

$$
C_{\mathrm{Co}^{\circ}} \cdot{C_{\mathrm{H}^{+}}}^{-2}=3.4 \times 10^{14}
$$

\subsection{The relation between the activation energy and $\mathrm{pH}$}

Reith et $\left.a l .{ }^{9}\right)$ reported that the activation energy $E$ for the second-order rate constant varied with $\mathrm{pH}$. However, no equation to express the relation between the values of $E$ and $\mathrm{pH}$ has yet been proposed.

The fact that the dependency of $k$ on $\mathrm{pH}$ varies with temperature, suggests that $E$ will be expressed as a function of $\mathrm{pH}$. Therefore, the Arrhenius plot

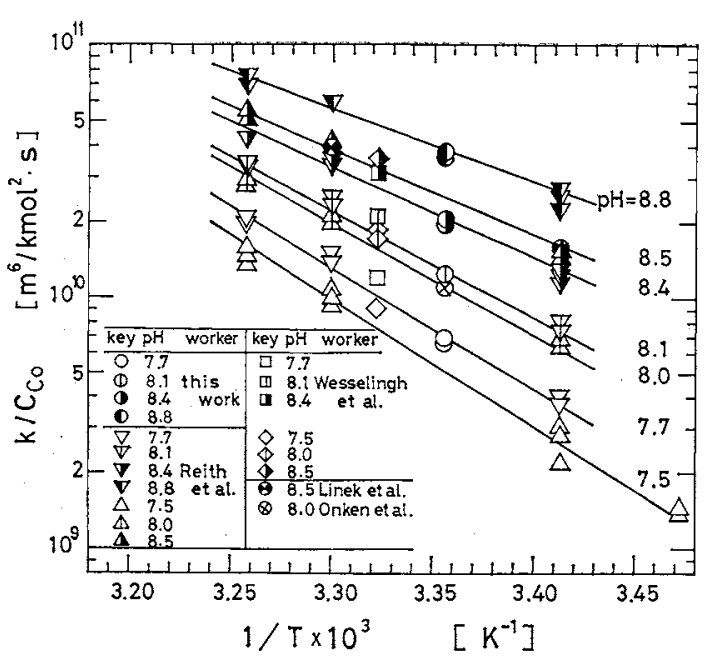

Fig. 3 Arrhenius plot of second-order rate constant

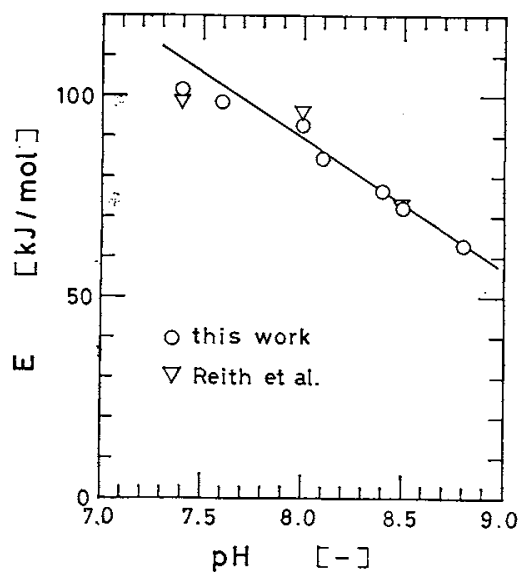

Fig. 4 Relationship between activation energy and pH

is shown in Fig. 3, including the results obtained by other workers $\mathrm{s}^{8,8,9,11)}$, where the values at $\mathrm{pH}=7.7$, $8.1,8.4$, and 8.8 were estimated by extrapolation of the straight lines in Fig. 2. Since the slope in Fig. 3 varies with $\mathrm{pH}$, the activation energy $E$ is obviously dependent on $\mathrm{pH}$. Thus, the value of $E$ is plotted against $\mathrm{pH}$ in Fig. 4 and the following linear relationship between $E$ and $\mathrm{pH}$ was obtained.

$$
E=350-32.5 \mathrm{pH}
$$

\subsection{A correlation of the rate constant}

Based on the effects of $C_{\mathrm{Co}}$ and $\mathrm{pH}$ on $k$, the value of $k$ at $298 \mathrm{~K}$ denoted by $k^{*}$ was correlated as follows.

$$
k^{*}=3.28 \times 10^{4} C_{\mathrm{Co}} C_{\mathrm{H}^{+}}{ }^{-0.68}
$$

where

$$
1.69 \times 10^{-5} \leqq C_{\mathrm{Co}_{0}} \leqq 1.69 \times 10^{-3}, 7.7 \leqq \mathrm{pH} \leqq 8.8
$$

The value of $k$ at another temperature can be expressed by using Eqs. (3) and (4). As a result, we have the relation

$$
\frac{k}{k^{*}}=\exp \left\{-\frac{350-32.5 \mathrm{pH}}{R}\left(\frac{1}{T}-\frac{1}{298}\right)\right\}
$$




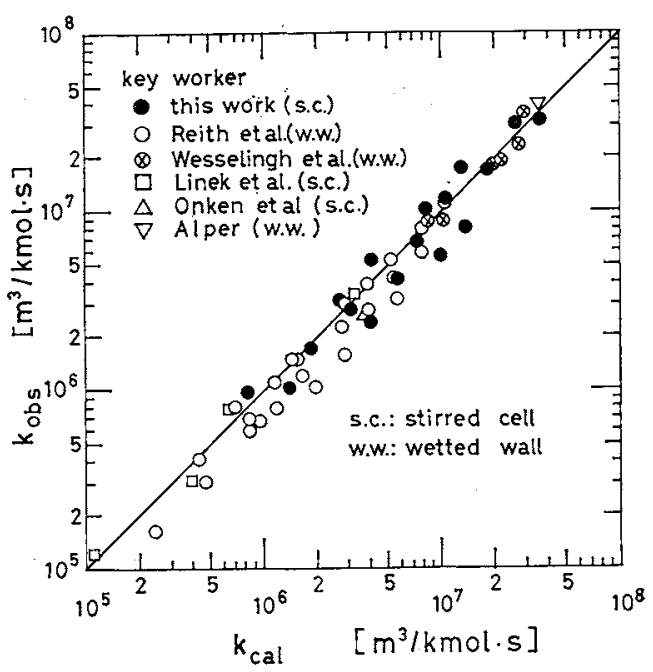

Fig. 5 Comparison of second-order rate constants calculated from Eqs. (4) and (6) with those observed experimentally

The expressions by Eqs. (4) and (6) were similar to those presented by Onda $\left.e t a .^{7}\right)$ in the first-order regime with respect to dissolved oxygen.

A comparison of the calculated values $k_{\text {cal }}$ from Eqs. (4) and (6) with the observed ones $k_{\text {obs }}$ is shown in Fig. 4. The values of $k_{\mathrm{ca} 1}$ are in good agreement with those of $k_{\text {obs }}$ for various conditions. Consequently, Eqs. (4) and (6) are found to be valid.

Nomenclature

$$
\begin{array}{ll}
A & =\text { interfacial area in the cell } \\
C_{\mathrm{Co}} & =\text { cobalt concentration } \\
C_{\mathrm{H}}{ }^{+} & =\text {hydrogen ion concentration } \\
C_{\mathrm{So}_{3}}{ }^{2-} & =\text { sulfite concentration } \\
\mathrm{C}_{\mathrm{SO}_{3}}^{\circ} & =\text { initial sulfite concentration at } \\
& t=0
\end{array}
$$

\begin{tabular}{|c|c|c|}
\hline$D_{\mathrm{O}_{2}}$ & $=$ diffusivity of oxygen & {$\left[\mathrm{m}^{2} \cdot \mathrm{s}^{-1}\right]$} \\
\hline$E$ & $=$ activation energy & {$\left[\mathrm{kJ} \cdot \mathrm{mol}^{-1}\right]$} \\
\hline$H$ & $=$ Henry constant & {$\left[\mathrm{Pa} \cdot \mathrm{m}^{3} \cdot \mathrm{kmol}^{-1}\right]$} \\
\hline$k$ & $=$ second-order rate constant & {$\left[\mathrm{kmol}^{-1} \cdot \mathrm{m}^{3} \cdot \mathrm{s}^{-1}\right]$} \\
\hline$k^{*}$ & $=$ value of $k$ at $298 \mathrm{~K}$ & {$\left[\mathrm{kmol}^{-1} \cdot \mathrm{m}^{3} \cdot \mathrm{s}^{-1}\right]$} \\
\hline$k_{L}$ & $\begin{aligned}= & \text { liquid-phase mass transfer } \\
& \text { coefficient in the cell }\end{aligned}$ & {$\left[\mathrm{m} \cdot \mathrm{s}^{-1}\right]$} \\
\hline$p_{\mathrm{O}_{2}}$ & $=$ oxygen partial pressure & [Pa] \\
\hline$Q_{A}$ & $=$ air flow rate & {$\left[\mathrm{m}^{3} \cdot \mathrm{s}^{-1}\right]$} \\
\hline$R$ & $=$ gas constant & {$\left[\mathrm{kJ} \cdot \mathrm{K} \cdot \mathrm{mol}^{-1}\right]$} \\
\hline$T$ & $=$ temperature & {$[\mathrm{K}]$} \\
\hline$t$ & $=$ time & [s] \\
\hline$V$ & $=$ liquid volume & {$\left[\mathrm{m}^{3}\right]$} \\
\hline$\gamma$ & $=\mathrm{H}$ & $\left(k_{L}\right)$ \\
\hline
\end{tabular}

\section{Literature Cited}

1) Alper, E.: Trans. Inst. Chem. Engrs., 51, 159 (1973).

2) Danckwerts, P. V.: "Gas-Liquid Reactions", McGrawHill (1970).

3) DeWaal, K. J. and J. C. Okeson: Chem. Eng. Sci., 21, 559 (1966).

4) Hikita, H. and H. Ishikawa: Kagaku Kogaku Ronbunshu, 1, 45 (1975).

5) Linek, V. and J. Mayrhoferova: Chem. Eng. Sci., 25, 787 (1970).

6) Linek, V. and V. Vacek: ibid., 36, 1747 (1981).

7) Onda, K., E. Sada, T. Kobayashi and M. Fujine: Kagaku Kögaku, 34, 79 (1970).

8) Onken, U. and W. Schalk: Ger. Chem. Eng., 1, 191 (1978).

9) Reith, T. and W. J. Beek: Chem. Eng. Sci., 28, 1331 (1973).

10) Sathyamurthy, N., T. E. Degaleesan, K. Chandrasekharan and G. S. Laddha: Can. J. Chem. Eng., 57, 145 (1979).

11) Wesselingh, J. A. and A. C. Van't Hoog: Trans. Instn. Chem. Engrs., 48, T69 (1970).

12) Yasunishi, A.: Kagaku Kogaku Ronbunshu, 3, 154 (1977).

13) idem: J. Chem. Eng. Japn, 10, 89 (1977).

\title{
EFFECT OF WATER ON BENDING STRENGTH OF GLASS
}

\author{
Yoshiteru KANDA, Masahiro HASEGAWA AND ToraJiro HONMA \\ Department of Chemical Engineering, Yamagata University, Yonezawa 992
}

In the previous papers ${ }^{1-3}$, the authors discussed the difference between dry and wet grinding of nine kinds of materials using a small ball mill, from a kinetic point of view.

It has been considered that the difference in grindability in different atmospheres may arise from the change of surface energy, the degree of dispersion

Received March 5, 1982. Correspondence concerning this article should be addressed to $\mathrm{Y}$. Kanda. of particles, the consumption of kinetic energy by water, the chemical reaction between water and material and some other reasons ${ }^{4-7)}$. However, there has been no satisfactory explanation because the quantitative effects of the above causes were not understood.

In this work, bending tests were carried out on glass material in order to investigate the quantitative effect of water on bending strength and crack prop- 